\title{
Dispositives of newness and change: academic organisations' discursive practice at the intersection of excellence and gender
}

\author{
Sarah Wieners ${ }^{1 凶} \&$ Susanne Maria Weber ${ }^{1}$
}

On the basis of a genealogical discourse analysis, Weber distinguishes four dispositives of creation. The 'new' is created and organised within systematic rationalities of creation. It emerges in (a) an organic cyclical transcendence, (b) a top-down pattern, (c) an entrepreneurial mode that designates man as creator and (d) a collective cyclical dynamic. The dispositives of man as creator and creation as an act are becoming particularly dominant in today's academic organisations and these dispositives systematically produce institutional programmatics and organisational strategies. In this paper, we analyse how the new emerges in two academic organisations. The starting points of our analyses are two institutional innovations that emerged in Germany in the 2000s: the Excellence Initiative and the gender equality programme. Although they derive from different fields of discourse, both innovations share common features. The Excellence Initiative required universities to relate discourses of excellence and gender equality to each other, and this article investigates how the new emerges in academic organisations to understand whether these innovations produce equality or perpetuate traditional inequalities. Based on Foucault's dispositive methodology, we use website analyses and interviews with gender equality officers and heads of earlycareer researchers' departments. We highlight the discursive connections between gender and excellence for early-career researchers and outline various discursive organisational strategies.

\footnotetext{
${ }^{1}$ Department of Education, Philipps University Marburg, Marburg, Germany. ${ }^{凶}$ email: sarah.wieners@staff.uni-marburg.de
} 


\section{Introduction}

brief exploration of the latest body of research on academia reveals that academia is being changed through knowledge sets that organise the institutionalisation of innovation strategies. The knowledge sets that we focus on in this contribution include excellence, internationalisation and gender equality (Marx-Ferree and Zippel, 2015; Riegraf and Weber, 2017). In this paper, we concentrate specifically on excellence and gender equality, which have been visible in Germany as 'new' political programmatics ${ }^{1}$ and legal frameworks in institutional programmatics, organisational strategies and performative practices since the 1990s (Münch, 2014; Peters, 2019). Whereas excellence discourses aim to build beacons of scientific achievement in German academia, gender equality demands stem from a tradition of changing patriarchal institutions and advocating for social change and equality. Within German policy agendas, gender equality and excellence discourses are related to the political strategy of the Excellence Initiative, a programme funded by the German Federal Ministry of Education and Research between 2005 and 2016, which was superseded by the Excellence Strategy in 2017. Both of these discourses emerge particularly in relation to the subject position of the early-career researcher. From a Foucauldian biopolitical perspective, the subject position of a potential progeny of excellence emerges at the intersection of economy and population (Weber, 2006). Nevertheless, organisations relate excellence and gender equality discourses differently to decipher specific relational patterns in terms of how newness in organising arises. What are those patterns, which dispositives of creation do they follow and how do these rationalities play out and relate in different academic organisations?

We employ Foucault's notion of the dispositive ${ }^{2}$ to perform an empirical study of the new in German academic organisations. Foucault defines the dispositive as 'a thoroughly heterogeneous ensemble consisting of discourses, institutions, architectural forms, regulatory decisions, laws, administrative measures, scientific statements, philosophical, moral and philanthropic propositions-in short, the said as much as the unsaid' (Foucault, 1980 , p. 194). However, the dispositive is not just the sum of these elements but also the net of powerful knowledge that can be established between them. As Parr (2010, p. 235) describes, the dispositive strategically standardises its institutions and techniques like a matrix. Dispositives have a dominant, strategic function (Link, 2010, p. 239) and organise the interplay of power and knowledge. From a genealogical perspective, Weber (2013a) distinguishes four different dispositives of creation: (1) creation as transcendence, (2) creation as act, (3) man as creator and (4) collective creation. Each of these dispositives carries specific notions of creation and change and each of these dispositives brings forth specific discourses in academic organisations. In this paper, we understand these dispositives as general, underlying rationalities of emergence and basic patterns of change and creation. For our empirical study, we analyse how two specific institutionalised strategies-the Excellence Initiative and gender equality strategies-evolve within and through these dispositives of creation. We analyse these two questions based on (1) organisational website analysis and (2) interviews with two institutional actors in the fields of early-career academics and gender equality.

This paper proceeds as follows. The first section outlines the dispositives of academia and introduces the dispositive of excellence. The second section introduces the dispositive of gender and discusses how gender and excellence connect in recent discourses and debates. The third section discusses recent changes in German academia and relates the two aforementioned dispositives to the German case. After this, we introduce our methodology and present the results of an empirical study on two German academic organisations in which two different dispositives of creation and innovation evolve. In the final discussion, we tie our results back to the four dispositives of creation presented in the second section and discuss the missing discursive innovation in these academic organisations.

\section{Dispositives of creation}

From a discourse perspective, normative, philosophical and ontological statements in a transversal reconstruction are analysed as 'material'. Instead of disciplinary or document-oriented logics of reconstruction, discourse analysis allows for the 'archaeological' uncovering of the 'monument' that organises the regulated practice of discourses (Foucault, 1973, p. 297). The ways in which the new arises differ according to different dispositives of creation. Weber highlights that these dispositives put 'societal and theoretical discussions about the converse with the new into a relation to power, knowledge, governance, and subjectivisation' (Weber, 2013a, p. 165).

The first dispositive of the new is the dispositive of 'transcendence'. This pattern of newness refers to an cyclical and organic concept of newness as we find it in nature (seasons, the cycle of life and death, etc.). This dispositive refers to the interconnectedness of everything, to a decentred subject, a wholistically embedded cosmological existence. From a genealogical perspective, this is the oldest dispositive of creation. We find this pattern in symbols and artefacts dating back almost 25,000 years. For example, the Venus of Willendorf, a work of art from the European Palaeolithic period, represents symbols of fertility (Kamper, 2003, p. 40). Historical images of procreation and female sexuality are performative signs of goddess cults, which have existed in numerous cultures and time periods. The dispositive of newness representing fertility and birth is universal and transcends time. Highly symbolic artefacts like the Venus of Willendorf symbolise the omnipresence of the generative dispositive in the cyclic re-creation of humankind. This cyclical and organic concept of newness exhibits an organic, biological quality. As opposed to a human-centred vision that brings forth the new, it represents an emergent, cosmologically embedded concept of mother earth and living together in harmony with nature. This magical connectedness is reflected in contemporary ecological conceptualisations and the Andean cosmology of the 'good life' (buen vivir).. Against a human centred vision of bringing forth the new, it stands for an emergent, cosmologically embedded concept of mother earth and of living together in harmony with nature (Acosta, 2015) and posthumanist conceptualisations (Alaima, 2008). It also connects to academic strategies of aesthetic transformation and ethical creativity, which refer to the transcendence of the being in present-day institutional strategies. Using meaning-based creativity within paradigms of ecology (Weber and Tascón, 2019) all connect to mindfulness (Weber and Heidelmann, 2019). This dispositive organises a singular, cyclical type of new creation.

In the dispositive of creation as act, the new comes into the world as a creation from a divine creator. It is diametrically opposed to the first and most ancient dispositive in its understanding of creation (Weber, 2013a, p. 168). Creating the new here refers to an exclusive practice of divine forces rather than universal human experience and creation. 'The singular-static type of power indicates an existing, not-to-be-questioned order. Opposing the cyclic structure of omnipresent creativity, time and space in this dispositive are static and linear, laid out timelessly in the horizon of either eternal blessedness or eternal perdition' (Weber, 2013a, p. 170). Both Greek mythology and Christianity leave the cosmological pattern of interconnectedness behind. Their conceptualisations of the new are the surfaces of emergence 
of this dispositive and stand for this representational model of monopolised creative power. The exegesis of divine signs is not an omnipresent activity of all, but in the hands of a few 'experts', while curiosity is regarded as a sin and human vice (Zorn, 2008); the transgression of rules is forbidden. Human subordination is organised by representational power. The creation of non-human idols separates the field into 'divinity' and 'subordinate' humans. This rationality of hegemonial power reproduces legitimate 'divine privileges' towards human subalterns. Within this singular and static type of power, the creative is spiritualised and turns into a patriarchal priviledge, which marginalises women, too. Creation out of nothingness in this rationality is placed into the logos and divides reason and nature. Today, this dispositive is relevant in organisational strategies of innovation. Academic strategies of innovation organising newness accordingly refer to the pattern of a for a predictable and controllable future. Expertocratism as well as referring to empiricist, quantifiable extrapolations of existing data like trend-surveys belong to this pattern and rationality of newness and strategy of innovation, which extends and reproduces the past into the future.

The dispositive man as creator refers to a third rationality: the divine creator. Human genius (Weber, 2013a, p. 170) shifts the rationality of creation towards development, design, conception and projection. Nevertheless, the subject position of the 'artistscientist' carries the aura of the divine: the artist aspires to resemble a god as an alter deus (Mareis, 2011, p. 365). The human genius iconically embodies the dispositive of a 'singulardynamic generativity'. Curiosity is a topos of self-determination. In fact, the extraordinary 'genius' informs the generalised creative subject of today. Patterns of subjectivation refer to the command of the new and lead to the enhancement of a selfdriven human creator. Schumpeter differentiates between the inventor and the entrepreneur. While the inventor brings forth the 'new' as a human creator, the entrepreneur diffuses the innovation. That is, the artistic 'act of creation' shifts into organised engineering and moves toward the subject of an entrepreneurial-or a more economically driven-self (Mareis, 2011, p. 234).

The fourth dispositive, collective imagination, again contrasts with the individual rationality of the creative subject. It shapes the idea of collective creation in the process of civilisation. One of its 'surfaces of emergence' is American pragmatism, such as Dewey's (1929) philosophy of education, in which-in an experiencebased collective learning mode-situated creativity allows collectives to build new hypotheses as a creative act. Real doubt, questioning and analysis of the given problem invite collective creative problem-solving. Strategies of casuistic analysis and experiential as well as evaluative examination lead to a collective sensibility and the spiral process of transcending the present in a reflexive and playful way (Dewey, 1967). This rationality of creation leads to collective strategies of systemic change, collective transformation in platform strategies (Weber, 2020) and the diffusion of the idea of 'open innovation' (Chesbrough, 2003) in societal innovation laboratories.

These dispositives of creation appear in strategies of organising and play out in academia's organisational strategies, too. Here, we especially can find the rationality of the 'entrepreneurial self and of the strategies of 'experts, evidence and prognosis'. Less to be found are he strategies of 'future by design' or the aesthetic transformation and ethical creativity of the self-transcending subject. As we will see in the following, the organisational strategies of newness and knowledge creation (Weber, 2013a, 2013b) within the he neoliberalisation of academia follow the dispositives of the human creator and creation as act. These two dispositives of creation become particularly dominant within the present patterns and rationalities of organising.
Neoliberalisation and the dispositives of creation in Academia. Although science has been practiced in many cultures for thousands of years, science is not transcendental. What is considered science depends on different epistemes, meaning that different systems of knowledge bring forth certain rationalities and styles of thought, doing economics and relating to the world (Barnett, 2011). Therefore, the university is an epistemic terrain (Weber, 2013a). Foucault distinguishes three epistemes since the 16th century: the episteme of resemblance and similitude (the Renaissance); the episteme of representation, ordering and differences (the classical episteme); and the modern episteme. The latter is characterised by a move towards the human being itself as the one who speaks, lives and works. In the modern episteme, the human being moves more and more into the researcher's field of vision (Foucault, 1971). In this era of the modern episteme, the modern university, the order of science and the academic field emerge from the dispositive of man as creator and creation as act. Over the past decades, however, universities have undergone global changes. Since 1980, academia has shifted towards new neoliberal governance (Peters, 2019), which actualises and modifies discursive patterns and relates different dispositives of creation to each other (Weber, 2013a). In the following subsections, we describe this shift with regard to the German academic field and the neoliberalisation of German academia. In this discursive shift, excellence becomes a dominant justification and legitimisation of academic knowledge production. While excellence in science has always been a criterion, excellence is reformulated in light of the neoliberalisation of science and produces new visibilities of scientific organisations and scientists (Münch, 2014).

From man as creator to the entrepreneurial self. The dispositive of man as creator relates to Foucault's description of the modern episteme and the knowledge order arising from the 18th century onwards. According to Foucault, a new epistemological rationality emerged in this period: the 'knowing man', which can be seen as a discursive formation. Instead of the identities and differences that determined classical thinking, modernity has replaced the principle of organisation, meaning that the relationships between elements have come to the fore. To analyse and classify no longer means to distinguish things and beings according to visible external characteristics, to represent them by names and to bring them into a tabular order. Instead, it is necessary to fathom their inner, hidden architecture. This dispositive is prevalent in the German university of modernity.

In Germany, the dispositive of man as creator emerged in specific ways in the university in the 18th and 19th centuries. In constitutive writings on German universities, Humboldt ([1809] 2010) defines universities as places of solitude and freedom, places of Bildung and places outside the influence of the state. Today, universities still uphold the Humboldtian ideal; however, the position of and discourses about universities have changed. Weber (2013a, p. 173) identifies this as the dispositive and an epistemic transformation from human creator to the entrepreneurial self, where new academic strategies of freedom and guidance are established. Educationally guided entrepreneurialism envisions an effective, economy-oriented self-organising subject. This rationality of manageability and self-design implies functional learning for a plannable and makeable future. To model, optimise and manage oneself becomes a dominant paradigm (Masschelein and Simons, 2012) in the rationality of self-enhancement (Maasen, 2010), which is relevant not only for organisational strategies but also for early-career researcher. In particular, the political and institutional strategies of the global knowledge economy and neoliberal discourses promising freedom and a free market rhetoric support a discursive shift in 
academia towards mobilisation and detachment as well as control and constraint (Ball, 2000; Miller and Rose, 2008). Excellence becomes a new paradigm in global academia. Indeed, educational philosopher Michael Peters (2001) discusses the connections between education, enterprise culture and the entrepreneurial self in the knowledge economy. Marginson and Considine (2000) discuss the 'Enterprise University' as a power model that can be observed in national cases (like Australia) and becomes relevant in neoliberal regimes, which have been criticised as regimes of 'targets' and 'terrors' (Jones et al., 2020, p. 363). The transformation of the neoliberal, entrepreneurial university in the knowledge economy was already being discussed in the early 2000s and has been empirically analysed in various studies (Peters, 2002). These studies have addressed this change and show how discourses portray both universities and researchers as entrepreneurial (Bröckling and Peter, 2017; Clark, 2010; Hamann, 2016). In this sense, the notion and subject position of the entrepreneurial self follows the neoliberal rationality of a knowledge economy. Neoliberal rationalities are making their ways into academia and organisational strategies of academic organisations, for example, in start-ups.

From creation as act to experts, evidence and prognosis: strategies of calculation and security. The second dispositive of the new in academia's organisational strategies is creation as act. Much like the neoliberal rationality in the dispositive of man as creator, Weber (2013a) finds the dispositive of creation as act in expertocratic strategies of organisational innovation and change in academia. These are closely linked to a specific type of bureaucratic power and a technical form of surveillance. A combination of free market rhetoric and intensive managerial control practices exists in today's German universities. In fact, the bureaucratic mode of control refers to the state-centred tradition and genealogically follows the dispositive we have introduced in the beginning. rationality of the dispositive of 'creation as act' and by this following the rationality of a singular-static order. The divine right to judge is reflected in the present in expertocratic rationalities. Strategies of evidence and prognosis combine and perform through strategies of calculation and security. Although neoliberal discourses promise more freedom through free markets, bureaucratisation introduces intensive managerial control and surveillance. Evidence-based strategies try to secure and control as well as predict and improve based on large datasets that must be monitored. Organisational strategies intend to bring unpredictable elements and possible deviations under control. The norm of efficient management combines with constant measurement and examination (Narr, 2011). Evaluation refers to predefined standards (Bröckling, 2013, p. 79) and likens this to a reproductive rather than inventive mode of newness. Evaluation, accountability and prognosis situate knowledge within a linear pattern of past, present and future (Weber, 2013a).

Much like Foucault's (1977) analysis of the panopticon wherein the gaze produces visibility and conditions prisoners' behaviour, scientific knowledge production is embedded in new disciplinary and governmental strategies of soft guidance of individuals (Miller and Rose, 2008) and organisations (Gertenbach, 2014). Angermuller (2010) identifies this idea in the transition to digital knowledge production through platforms such as ResearchGate or Google Scholar. These platforms allow a regime of visibility that opens up new possibilities for monitoring and controlling scientific production and academics, who can now be ranked according to their impact on the field. The same logic applies to organisations that are ranked according to their scientific impact. Much like researchers, the social technology of rankings makes highly diverse entities measurable through quantitative methods. Hammarfelt et al. (2017, p. 395) thus conceptualise university rankings as 'calculative devices, which contribute to the establishment of a market'. Both individuals and organisations shift to the centre of attention and change the way knowledge and the new are produced. The imperative for knowledge creation is no longer truth and producing knowledge in solitude and freedom as Humboldt once demanded. In the shift of the dispositive creation as act, knowledge production now adheres to the neoliberal principle of surviving in a competitive environment. Knowledge is no longer created for its own sake but rather in relation to positioning practice in the academic field. Nevertheless, the strategies of visibilization can be utilised in bureaucratising ways, which still follow the rationality of control.

\section{Gender equality and early-career researchers in German Academia}

Thus far, we have shown how the new is produced in different dispositives and how these dispositives of creation of the new manifest in different epistemes. In Germany, two institutional innovations have emerged from these dispositives. Newness enters academic organisations through the institutionalisation of gender equality demands and excellence discourses. Though gender equality and excellence became related in their history in the academic system, they began from different aims.

The Excellence Initiative ${ }^{3}$ was funded by the German Ministry of Education and Research from 2005 to 2019 and aimed 'to promote top-level research and to improve the quality of German universities and research institutions in general, thus making Germany a more attractive research location, making it more internationally competitive and focusing attention on the outstanding achievements of German universities and the German scientific community' (DFG). The Excellence Initiative had pools of funding directed towards three different targets: (1) future concepts, (2) research clusters and (3) graduate schools. The Excellence Initiative combined gender equality and excellence by declaring gender equality a criterion of excellence. Gender equality thereby became a competitive factor in the German academic system.

Why should academic careers and gender equality be reformed? Academic careers in Germany have long been an individual pursuit (Ben-David, 1968; Schwarz et al., 2018). Because of the double mission of research and teaching, the doctorate in Germany was based on a master-student relationship in the $19^{\text {th }}$ century. The doctorate was not funded, and the path to professorship was a 'wild hazard' (Weber, 1921), or a game of luck. However, Weber did not treat this as a problem but rather regarded it as a mark of quality because ultimately only those who dedicated their lives to science would become professors. Today, the idea still prevails that professional success can be attributed to one's own extraordinary talent and that a scientific career and scientific achievement are free of social influences (Schmeiser, 1994). However, this ideal has been intensively discussed in social studies of academia. Engler (2001) examines academic personalities from a Bourdieusian perspective. Academic personalities, she argues, are not only based on academic achievements but rest on recognition in the academic field. Academic success is therefore mainly a process of attribution in the 'scientific game' where gendered attributions marginalise female academics. Based on interviews, Engler shows that women are not excluded from doing science but are excluded from the scientific games of recognising and attributing academic success (Engler, 2001, p. 458). These processes have been further highlighted in gender research on academia. Studies have shown that gender differences are constitutive in academic institutions and become relevant for academic success in practices like doctoral supervision or networking (Beaufaÿs, 2003; Kahlert, 2015; Krais, 2000). Recent 
research by Elven et al. (2018) and Schwarz et al. (2018) shows how trajectories in academia evolve as an interplay of habitual and organisational processes, the latter of which are-as demonstrated-transforming. The interplay of habitus and organisational processes brings forth and prolongs inequalities.

A few years ago, Weber's depiction of embarking on an academic career as a 'wild hazard' attracted renewed attention, and it is now often used to discuss the situation of early-career academics in Germany (Kreckel, 2016, p. 12). While Weber saw no problem with the wild hazard, different political actors have criticised the academic career path in Germany. For a long time, doctoral studies were structured as a master-student relationship, and they have been institutionalised in the role of the researcher since the 1960s. Based on the conclusion that the number of doctoral candidates was too low and that the average age at which candidates finished their $\mathrm{PhD}$ was too high, the Council of Science and Humanities (Wissenschaftsrat) proposed to systematise and structure the doctorate through organisational forms such as graduate schools. This initiative was first taken up by the Deutsche Forschungsgemeinschaft ${ }^{4}$ (DFG) in the 1990s and a few years later became part of the Initiative for Excellence, a programme of the federal and state governments to stratify and vertically differentiate the German science system. Conceived by the German Council of Science and Humanities as a reform model, graduate schools advanced to become a form of qualification and funding for outstanding research and an elite of doctoral students (DFG, 2019a, 2019b). As Bloch (2018) points out, a 'boom in doctoral programmes' occurred (and continues), so that it is only with the graduate schools of the Excellence Initiative that the field of doctoral training was born as a phase that has to be actively shaped by academic organisations. The female scientist in particular became the focus of attention: it was she who had to be supported in order to adjust gender imbalance in science.

The institutionalisation of gender equality in German academic organisations stems from the second women's movement of the 1970s and 1980s. Unlike in Sweden, where gender equality was introduced by the state, gender equality in Germany was established bottom-up by the women's movement as a critique of the West German welfare and the male breadwinner models. Gender equality officers were first introduced in German universities in the 1980s and were institutionalised in the revision of the legal framework for academia (Hochschulrahmengesetz) in the 1990s. In Germany, gender equality policy is largely anchored as a corporatist principle in public organisations and is characterised by the political representation of 'women's' or 'equality interests' in the form of elected representatives (Weber, 2017, p. 192). At the beginning of the 2000s, as competition for financial, personnel and symbolic resources increased, gender equality policy was introduced as an evaluation criterion for scientific excellence in science and higher education policy programmes of the federal and state governments.

Given that very few women participated in academia, especially as professors, gender equality became institutionalised in the 1980 s due to women's demands for participation. Since the 1990s, the share of women in the academic system has increased. Whereas the share of female professors was $8.2 \%$ in 1999, their share in 2018 was $24.7 \%$ (Destatis, 2019). Gender researchers have highlighted how this change has been co-opted by neoliberal discourses. While the second women's movement fought for justice, the neoliberal reformulation turned women into human resources. With the combination of excellence and gender equality discourse, a new subject of interest has emerged: the female early-career academic as the 'subject of excellence' (McRobbie, 2004, p. 257). Research on gender equality and discourses of excellence discusses this discursive change and the position of 'excellent young researchers' in relation to the neoliberal reformulation of gender equality demands and the individualisation of structural inequalities that emerged within the neoliberal paradigm (Blackmore, 2019; Fraser, 2009; Rottenberg, 2014). The neoliberal reformulation now promises women that they can achieve anything if they try hard enough and invest in their education; however, this hides the structural inequalities that still exist and that become evident in the gender pay gap (Burkhardt et al., 2019; Goldan, 2019) or the ratio of male to female professors in Germany (Destatis, 2019). Overcoming structural inequality is now the task of each individual. The individualisation of structural differences therefore leads to 'unspeakable inequalities' (Gill, 2014, p. 509).

Research questions. Hence, in the field of science, there are two institutional innovations that originally began from different ideas but that now share similar discourses. In the course of the German governance reforms, science organisations were given the task of independently positioning themselves in the field and pursuing their own goals. Organisations refer to the institutional innovations of excellence and gender equality in different ways, but how do the dispositives of creation play out in academic organisations and organising, and which institutional programmatics and organisational strategies evolve in the two compared organisations? In which mode does the new manifest itself? Do these new institutions produce equality, or are old inequalities perpetuated?

\section{Methodology}

In this paper, we employ the dispositive as a research methodology (Raffnsøe et al., 2014; Wieners and Weber, 2019). Based on Foucault, we understand the dispositive as a 'system of relations that can be established between [...] elements'. It is the relations-or the net, as Foucault calls it in The Will to Knowledge - that produce power and knowledge, which Foucault maintains always work together. Knowledge is therefore never pure but is rather a product of a certain dispositive that brings forth discourses and subjectivities. We understand the dispositive as a power-knowledge formation that results in a specific organisational modus operandi (Weber, 2013b).

In terms of analysis, dispositive analysis allows the connection of discourses and subjectivities to power-knowledge and its strategies. Thus, dispositive analysis makes two things clear: (1) that what is supposedly given-for example, subjectivities-has emerged under certain historically contingent conditions and through different practices and (2) that questions of power are always connected with the historically contingent conditions of the dispositive (Bührmann, 2014, p. 43). In social research, the dispositive "lay[s] bare a social formation and transformation of the conditions for human agency, which have a determinate impact on how we think, feel, act, and imagine our future without determining what we do completely' (Raffnsøe et al., 2014, p. 275); this means that discourses assume their concrete and material form through dispositives. The powerful network of organisational dispositives provides subject positions and speaking positions that can be occupied by professionals. As such, they are permeated by the power-knowledge stocks of discourses. The dispositive perspective therefore offers the advantage of dissolving the dichotomy between subject and organisation and of focusing on the practices and processes of organising (Wieners and Weber, 2019).

Six German academic organisations ${ }^{5}$ were analysed with regard to how their discourse regarding early-career researchers is structured. All of the analysed organisations were publicly funded academic organisations, with four universities and two 
extramural research organisations. Three of the universities had received funding in at least one of the three funding pools (future concepts, graduate schools, research clusters) of the third round of the German Excellence Initiative from 2012 to 2018. The two extramural research organisations were not eligible to apply for funding, but their working groups could be part of a university's research cluster. The organisational dispositive of these organisations was investigated via two different research approaches: (1) website analysis and (2) interviews with organisational professionals. The multimodal website analysis was conducted between March and June 2017. The analysis was oriented according to van Leeuwen's (2011) structure and categories of website analysis and took elements of Panofsky's image analysis into account. We first analysed each modality_images, design, text-individually and then considered the interconnections and relationships in the organisation's website architecture (Weber et al., 2018). Starting from the homepage, we followed the links that led us to the organisation's website on gender equality, excellence and early career researchers.

The interviews with university professionals were conducted in the period from July 2017 to January 2018. While the first part of the interview intended to elicit details about their work as institutional representatives and the politics and policies of their organisations, the second part involved short statements addressing different stakeholders in the organisations (other institutional representatives and early-career researchers) and the Federal Ministry of Science. ${ }^{6}$ Both the interview and statements were recorded with a Dictaphone. If the participants agreed, the final statements were also recorded on video. The interviews were conducted on the basis of interview guidelines. A total of 10 interviews were conducted that lasted $\sim 1.5 \mathrm{~h}$ on average.

In contrast to hermeneutic approaches to interviews in which the scientist reconstructs the 'actual' meaning behind what is said in the interview, discourse-analytical research takes on a radically de-ontologising perspective. In a discourse perspective, knowledge and meaning are discourse, and these discourses pervade and constitute the social; they are performative (Butler, 1996). Subjects draw on these discourses when they speak and act and thus generate spaces. This means that meaning is generated via the interaction of subjects and objects, or in the interaction of the differently situated subjectivities of the researcher and interviewee (Bührmann and Schneider, 2016; Jergus, 2014). Our analysis posed two analytical questions: (1) 'Who speaks?' and (2) 'How is speaking possible?'. The first question aims to examine which knowledge and which truths underlie the institutional programmatics that constitute the organisational space and thus the speaking positions of the interviewed institutional professionals. The second question focuses on the institutional professionals and their speaking practice as a performative practice; that is, from a performativity perspective, their speaking positions are created in and through their speaking as we understand discourse as performative. In short, speaking brings forth discursive realities. These realities are however polyphonic so that subjects have to negotiate the ambivalence of discourses. We understand discursive strategies here as the non-intentional strategies or the 'actually realised patterns' (Weber, 2018, p. 599) of the subjects' ability and modi to act.

\section{Results}

In this section, we first introduce the global player organisation (GPO) and then the aspiring organisation (AO). Afterwards, we compare and discuss how the new emerges in these two organisations. We chose to examine these organisations because they both declare a strong commitment to excellence; however, the new emerges in different dispositives, which holds political consequences.

\section{Global player organisation}

Institutional programmatics. The GPO is a large, publicly funded, extramural research organisation in Germany that positions itself as an autonomous player in the German academic field. In its institutional programmatics, it does not see itself as competing with German academic organisations. Its points of reference are instead the elite US organisations 'Harvard, Stanford, Yale' (ECR GP, 400ff). To compete with these organisations, the GPO needs to maximise its full human capital potential through the best researchers. As the head of the early-career researchers department said, the organisation's mission is to 'maximise the potential [pause] of the best male and female scientists' (ECR GP, 470ff). In this organisation, researchers are primarily regarded as human resources. As the head of the early-career researchers department (ECR) said, the organisation is about how one can utilise the potential [pause] ehm (.) of the best scientists in a simply wonderful way' (ECR GP, 471ff).

These institutional programmatics become visible in the image on the gender equality website, ${ }^{7}$ where gender equality and earlycareer researchers' discourses are connected. The image depicts five people, two of whom can be identified as male and three as female, and they are dressed in reference to a particular job. They are all wearing lab coats, and each person in the picture is holding something in their hand that is related to work, such as a pipette. There is only one person in the picture who is not holding something that is not a work tool per se: the man in the back is holding a paper cup. Though the lab coats unite the people in the picture, each individual in the picture has a further dimension that singles them out. There is a Black man and a White man, a woman with a scarf and a woman that can be read as Indian, Pakistani or Middle Eastern. Each of these individuals can be considered a token and represents a category of inequality. Though the researchers are standing together, they do not form a group in the way that they are interacting with one another. They are looking in different directions; nobody is looking directly at the camera.

Since the website is a highly intentional space-it is the 'showcase' of the organisation (Kühl, 2011, p. 95)-the organisation clearly wants to display that it is a diverse organisation in which different people are represented. However, the depicted diversity is a very ordered diversity. It is not a natural situation. Although all the people are shown with working material, they are not in a laboratory but rather stand in front of a concrete wall, and although they are similarly dressed in lab coats and thus are represented as equivalent lab workers, the perspective of the picture breaks up the equal representation. The perspective of the picture aligns with the head of the older White man with the paper cup, who is positioned somewhat in the background. Although everyone in the picture is supposed to be represented equally, the picture suggests an implicit gender, ethnicity and age order with the older White man as the climax. This genderspecific symbolic order of GPO is both visible in this picture and echoed in a statement from the interview: 'I think the best advocate for [pause] women's rights is an old man [...] because he is the one that everyone listens to' (ECR GP, 552ff).

From a strategy-of-discourse perspective, the discourse in GPO follows a very intentional performative strategy. The organisation's hegemonic programmatic is that the organisation is already excellent. Since it is an intentional, performative discourse, the tactics of discourse follow the question 'Who can be heard?' The answer is only those who commit to the hegemonic discourse; deviant positions are delegitimised and sanctioned. Though this organisation makes a heteronomous claim, it brings forth a rather heteronomous organisational discourse in which gender equality is reformulated to meet the demands of the organisation. The head of the ECR GPO conseptualises gender discourse as 
regimentation and restriction and thus as an attack on the organisation's freedom:

In the case of equal opportunities, I believe that we often hear from politicians [pause] that ehm: we are not quite honest anyway, that we are trying to [pause] ehm: [pause] ehm: [pause], yes, to get out of the affair one or two times and that our goals, the way we set them [pause], are not as ambitious as they could be [...] because I think [pause] at the [GPO] the problem is that we don't let ourselves be seen in the cards very much. (ECR GPO, pp. 876-822)

This approach also means that inequalities remain unspeakable, thereby rendering structural inequalities due to gender or ethnicity invisible. As the head of the ECR GPO stated, generation rather than gender is the dividing dimension. If one only considers women and gender equality, one would miss another important dimension. Instead, one must ask, 'What do young people need [...] to be interested in a career in academia?' (ECR GP, 364ff).

In the interviews with the head of the ECR and the gender equality officer (GEO) - who are understood as 'surfaces of the emergence' of organisational discourse-different discourses were brought forth in the negotiations regarding early-career researchers. In the organisational discourse described, a structural tension is already apparent. This discourse becomes also evident in the speaking practice of the two interviewed institutional representatives. While the ECR reconstructed the relationship of excellence and gender equality as 'exciting', the GEO was tense; i.e., she struggled to reconcile gender equality and excellence in the same way as the organisational discourse.

Head of the early-career researchers department. When analysing the interviews, we began with the question of how speaking is possible in this organisation, and we observed that the discourse in this organisation created speaking positions that were marked as 'exciting' (ECR GP, p. 42) for the head of the ECR but that put the gender equality officer is tense It is interesting to add that excitement and tension in German both mean 'spannend', so the same word refers to different emotions. For the head of the ECR, this term meant excitement, while for the gender equality officer it meant tension. Both discussed the organisation a great deal, but their style of speaking was very different.

The head of the ECR spoke in an international management style when he discussed the organisation. His speaking practice was representational. It was official and collective, as reflected by the fact that he mostly used the expression 'we as an organisation' (ECR GP, p. 91) even if he was asked for his personal opinion. In this interview, personal interest and personal commitment to the issue of early-career researchers were linked very closely to the organisational position and especially the organisation's president: 'Our current president has also recognised this issue, for him it is ehm relatively clear that there are just two alternative, several alternative career paths and one is not better or worse' (ECR GP, pp. 120-123). His speaking practice shows no antagonistic relationship between organisational interests and his own positions. His speech identifies with the organisation, giving him a valid discourse to construct his way out of academia as an acknowledgeable trajectory in this organisation. Since he is an organisational representative, his speaking practices in the organisation follow the discursive strategy of casting shadows, meaning that he sidestepped negative accounts of the organisation by casting shadows on them and instead illuminated those areas that show the organisation's leading role in the academic field. When talking about the political demands of gender equality and addressing that the organisation has not yet fulfilled these demands, he spoke of the 'special path' (ECR GP, p. 719) that the organisation is undertaking.

Gender Equality Officer. The speaking practice of the GEO is quite different from that of the head of the ECR. She made use of the official organisational discourse and expressed the positions of the organisation using the same words as the head of the ECR, but she also used sarcasm. For example, after presenting the official organisational vision, she ended the sentence with 'We are an elitist club, right?' (GEO GP, p. 564). When asked whether the science organisation was participating in special, financial support programmes for gender equality, the GEO first answered curtly and then evaded speaking. She replied,

Yes, I'm not a friend of such special programmes now, honestly so or uh yes so it depends on what, but uh this female professor programme mh yes, I don't know/ don't know how I see it uh yes, so I think the windfall effects were also greater than uh than that ACTUALLY new women there have moved into new positions [quick: moved], but don't know so I have it now it's too private now [quieter: just here, but.]. ${ }^{8}$ (GEO GP, pp. 456-461)

Although the question refers to the organisation and to a topic within her field of work, she withdrew from speaking in the interview situation because the topic was 'too private' (GEO GP, p. 461). This indicates a silencing of certain gender equality positions within this organisation. The institutional programmatics of this organisation play out in such a way that gender equality becomes only partly hearable. Gender equality-and with it the speaking position of the GEO-incline toward a subaltern position. For example, her refusal to speak can be understood as a silencing resulting from the organisation's gender discourse. The GEO had to make a horizontal sidestep to position herself and be heard. Unlike the head of the ECR, whose self-concept is that of an organisational representative, the GEO described herself as a consultant (GEO GP, p. 310) who comes into the organisation to neutrally consult and give advice. Here, she referred to the practice of management consulting, which seems to allow a fit and a sort of legitimisation between her self-positioning and the organisational discourse. She described herself as attached to the organisation but not part of it: she is 'outside the line' (GEO GP, p. 312). From this position at the margins, she tries to undertake counter practices to enlarge speaking zones for gender equality.

\section{Aspiring organisation}

Institutional programmatics. The $\mathrm{AO}$ actively subscribes to the excellence discourse. While the GPO presents itself as excellent per se, the AO's website contains many explicit references to the Excellence Initiative as well as indicators that are intended to show the excellence achieved so far. For example, the website contains a reference to the organisation's rankings and the clusters of excellence it has achieved. The modus of this organisation can therefore be described as aspiring: it aspires to be among the 10 best German universities and applies an entrepreneurial discursive strategy to reach this goal. It regards itself as well as its members as entrepreneurial in the modi of creation (Alvarez and Barney, 2007).

For this organisation, gender equality and early-career researchers are important topics in relation to social inequalities and the Excellence Initiative and gender equality demands of the German Research Foundation. Gender equality and early-career researchers' discourses are part of the positioning practice of the organisation, which sees itself as a holistic employer. In contrast to the GPO, which is interested in individuals solely as human 
resources and which regards its employees as optimal, unattached scientist, this AO sees itself as part of the lives of individuals.

The AO is an organisation that sees itself as interested in the lives of its members, who are individuals embedded not only in the organisation but also in a social sphere which has an influence on the careers and life paths within the AO. This understanding is particularly evident in the discourse on gender equality. In contrast with the discourse in the GPO-wherein the individual is regarded as a human resource for international competition-the organisational discourse in the AO revolves around the different social spheres within which the individual is embedded. This is shown, for example, in the image on the gender equality webpage. ${ }^{9}$ Whereas the picture on the webpage of the GPO was taken inside, the picture on the AO's gender equality webpage shows the silhouette of different people-men, women, children - and activities in a park in front of a town skyline. There is a woman in the middle of the picture. Unlike the GPO's website, where the axis leads up towards the man like a pyramid, the axis in this picture leads down and points to the woman. She is the centre of attention. Like the other people in the picture, the woman is also presented in action and seems to be talking on the phone. There are also children in the picture. However, they are not interacting with the woman but rather with a man on the left side of the picture. Thus, several discourses arise and materialise, including questions of the redistribution of caregiving and new fatherhood, notions of entrepreneurialism and managerialism of life, and work-life balance. Whereas in the GPO everything was focused on the organisation and life within the organisation, the $\mathrm{AO}$ presents its individuals and places them at the centre of its organisational life.

Although the individual is constructed as an entrepreneurial subject, individuals are still perceived as living human beings that are engaged and restricted by cultural norms in positive and negative forms. Gender equality programmatics are grounded in a political discourse and hold the programmatic that there must not be any inequalities due to biological differences. At the organisational level, this leads to mentoring and empowerment programmes for women and professionalisation programmes for early-career researchers.

The strategies of discourse in this organisation follow a different approach than in the GPO. In the GPO, the excellence discourse is static and hegemonic and suppresses or marginalises certain gender equality discourses. Conversely, in the $\mathrm{AO}$, discourses are still in process as they are still being elaboreted. Concerning graduate schools, the ECR AO stated,

There is of course also the experience of graduate schools in the background [...] we also, um, see that as a kind of a practical test or to see that it works, and that it goes down well, and that is then transferred to the next level to say 'If it fits in these small institutions, we have to do a bigger one', i.e. in the overall context, somehow, uh, all doctoral students, and that was also one of the intentions, uh, one of the motivations that all doctoral students have in a/or access to structures that until now have only been reserved for members of graduate schools (ECR AO, pp. 555-568).

Instead of supressing positions, speaking zones are broadened, speakers mobilised, and chances redistributed. Since the organisation is striving for excellence, the process of becoming what it wants to be is a reflexive and validating practice in itself. In its aspiring and striving mode, discursive spaces open up.

Neither interviewee spent much time discussing the organisation as a static building that is excellent per se, referring instead to processes that hinder gender equality work and doctoral student programmes. Both the speaking practice and the speaking position of the GEO as well as of the head of the ECR are in process, they are still negotiaging their positions. The excellence discourse in this organisation is not dominated by a neoliberal, individualising discourse but rather adopts an approach of mutual, entrepreneurial creation. In this organisation, the GEO and ECR collaborate informally to create workshops and programmes: 'The whole thing happens largely in cooperation with the Equal Opportunities Office here in [the AO]. We have a good exchange, which is also because I get along very well with the advisor to the GEO [...], we conduct workshops, uh, "Doing a doctorate as parent" we had, uh, then this "Women in Science" (ECR AO, pp. 368-372). Though excellence and the Excellence Initiative are one major discourse, it is not the main discourse but rather the thread that ties the gender equality and early-career researchers' discourses together. Both interviewees referred to excellence and gender discourses in the organisation as processes in which they have to manage their opportunities from their speaking positions; this means that to speak and be heard, they have to manage their opportunities and are highly flexible in processes when it comes to implementing and advancing their issue in the organisation.

Head of the early-career researchers department. The head of the ECR spoke in an entrepreneurial style akin to that used in young start-up companies. ${ }^{10}$ In fact, he regarded the founding of the graduate school where he works as his third 'start-up' (ECR AO, p. 34). He presented himself as a self-made man, citing how he had to start from scratch and 'organise courses myself (ECR AO, p. 127). He explained, 'In the beginning, I did at least $70 \%$ of the courses myself [...] do them myself, build them myself, offer courses myself [...] but I have to do something to get more money' (ECR AO, 134, 139ff, 213ff).

His style of speaking fit his self-presentation as an entrepreneur in the organisation who had to build a new department. His language was interspersed with many English words even though he might easily have used German terms, such as the English term 'toddler room' [ECR AO, p. 917] rather than the German equivalent. His performative practice can be characterised as that of an intrapreneur. He is an activist for social change, as the following quotation supports.

And then I saw the scissors diagram [...] And THAT was still another moment when my eyes were opened and I said 'Yes, that's actually right/ something is really going wrong here', when we have so many female students, or uh, well, somewhat more female students than male students, (pause) that in the area of doctoral studies is perhaps still holding up but is already decreasing, but then this break comes and suddenly uh, so many women decide to turn their backs on science because something is going wrong (ECR AO, pp. 347-352).

The head of the ECR thus constantly considers how to improve organisational processes and collaboration in tandem with reducing social inequalities.

Gender Equality Officer. On the other hand, the GEO speaks in a very reflexive way and seems to constantly process herself. Upon being asked how she collaborates with others in the organisation, the GEO first named several projects in which they work together with the ECR and the university administration. She reflected on how she has to communicate in the organisation, which she claimed must be done in an appreciative way, so we have to think carefully about what terms [...] will be used to present this topic' (GEO AO, p. 554).

She described herself as a manager for the topic of gender equality. She was not particularly interested in the topic of gender equality but more so in the 'managing' (GEO AO, p. 13), and her 
performative practice reflected a micro-political awareness of discursive spaces. To make her themes and concerns visible in the organisation, she connects with already existing organisational logic and speakabilities of objectifiable indicators to justify gender equality: 'my focus is [...] monitoring, statistics, so how we can verify that we are really there on the right track' (GEO AO, 67f). At the same time, she used discursive openings to place her topic; for example, she speaks of 'jumping on the bandwagon' ['auf den Zug werden wir mit aufspringen'] (GEO AO, p. 1205), meaning that she opportunistically but entrepreneurially uses certain opportunities to create change.

How does the new emerge? In the first section, we introduced four dispositives of the new, meaning patterns of how the new evolves and is organised. The four dispositives of creation are transcendence, creation as act, man as creator, and collective creation. We argued that in German science policy discourse, excellence and gender equality were introduced as 'the new' through discourses from the political field. In the following discussion, we relate this political discourse to the organisational discourses and their position in the field and ask which dispositive the new emerges through within the two presented organisations.

Global player organisation-the 'new' as singular-static generativity. The GPO positions itself as an already excellent, boundary-transcending organisation that is in competition for the best human potential with elite US institutions. Although this organisation is publicly funded, it positions itself as autonomous and produces a heteronomous, hegemonial discourse. In this organisation, excellence is not new. It is what has always been there. It is the essence of the organisation. The new in this organisation is only gender equality. Gender equality is not a demand that has arisen from the organisation but is reconstructed as a demand from outside the organisation. Within the organisational discourse, gender equality is constructed as alien and forced and impairs the legitimisation of excellence within the organisation.

How is the new-in this case, gender equality-organised? In this organisation, excellence is a hegemonic discourse, and the excellence discourse is apparent via free market rhetoric and intensive managerial control. Newness in this organisation has to be inscribed into the excellence discourse, as is apparent in the discourse that unfolded in the interview with the GEO. Gender equality as a claim for more social and organisational equality in opportunities has no weight in this organisation. Its sole legitimisation is based on neoliberal human resources management. Newness is organised within a singular-static generativity in which gender equality is under surveillance to produce the hegemony of neoliberal excellence.

This singular-static generativity means that the institutional innovation of gender equality is not treated as innovative. What is treated as static in the organisational discourse, however, is excellence and how the organisation found its own way of reformulating gender equality to gain further legitimisation from its political stakeholders. As McRobbie (2010, p. 91) states, the recognition of subjects of governmental attention represses any necessity for feminist critique.

The aspiring organisation-dynamic generativity from individuals towards alliances. The entrepreneurial modus features the dispositive of man as creator, which actualises in the discourse of an entrepreneurial self. In this dispositive of dynamic generativity, desirable futures are the reference point of professional action. Academic professionals create pressure points to transform existing institutional programmatics and strategies. They intend to widen organisational speaking zones and open up the organisational discourse. The orders of attention are oriented towards windows of emerging opportunities in the process of organising.

To be successful in the Excellence Initiative, academic organisations have to demonstrate how they intend to support gender equality. Since these organisations depend on financial resources from the Excellence Initiative and recognition from other organisations in the national field, they must process and actively work toward and present their achievements. As the AO's position is not yet fixed, its professionals work at the level of constructing realities and shaping 'politics of truth' and legitimisation. Because it is still aspiring, it is in a collective learning process. Although we can see the man as creator dispositive in its recent actualisation-the 'entrepreneurial subject'-in this organisation, we can also see the tendency towards micro-alliances, micro-political co-creativity and cocreation of collaborating entrepreneurs, as shown by the informal cooperation between the GEO and the ECR.

In this organisation, the new evolves based on the dispositive of man as creator, integrating micro-alliance practices of co-creation in a process in which social inequalities arise and are dealt with. Thus, gendered inequalities are dealt with from an equal opportunity value set. Micro-alliance activities are processed and legitimised in the entrepreneurial style. In this example, the discussions and critiques of feminist researchers referring to neoliberal co-optation of feminist gender equality demands are evident. Although the $\mathrm{AO}$ is concerned with gender equality issues and invests effort into changing gendered academic and organisational norms, this is happening in an entrepreneurial mode and is based on an entrepreneurial legitimacy and legitimisation.

\section{Dispositives of transformation-heterotopias missing}

As demonstrated, academic organisations follow different attentional orders and bring about different politics of reality. To be heard, the contested topic of gender for the AO can only 'jump on the bandwagon' of legitimate academic entrepreneurialism. In the case of the GPO, gender equality must be realised via dissident micro-political and seemingly neutralised consulting strategies. These regimes of newness can both pose risks and unintended effects such as distortions and a loss of innovation potential. Both rationalities and legitimate orders of innovation-that of a 'managerial revolution' (Maasen and Weingart, 2008, p. 142) as well as the bureaucratic rationality of control, formalisation and regulation-carry dysfunctional elements or are themselves dysfunctional by establishing vicious circles (Braun, 2008, p. 117), which may lead to decline, stagnation and paralysis. As introduced in section "Dispositives of creation", there are however four dispositives of creation. While the dispositive of men as creator and the dispositive creation as act seem to bring forth rather dysfunctional strategies, the other two dispositives-dispositive of transcendence and dispositive of collective imagination-can be regarded as the road least travelled.

While the empirical cases are still based in entrepreneurial discourses, it does not mean that there is no new. Foucault (1984) reflected on heterotopic spaces as spaces that present a difference from normality and the ordinary. In this sense, the two other dispositives mentioned before offer visions for alternative and integral organisational strategies. Organisational models following the concept of public spaces-of the agora-suggest the unconditional space of 'truth telling' (Parrhesia) and an open, public university, which allows organisational members to cocreate alternative futures. The dispositives of ethical transcendence and collective innovation would lead into an organisational 
practice that opens spaces for individual and collective reflection, imagination and transcendence (Weber, 2013a). The transversal agora would then integrate rationalities between 'critique' and 'design'. Personal embodiment as well as collective imagination and co-creation would enact the university as a collective space of 'desirable futures'. In this sense, it might travel the path towards an open university-transcending incommensurability.

\section{Data availability}

All data analysed are included in the paper.

Received: 20 February 2020; Accepted: 27 September 2021;

Published online: 22 October 2021

\section{Notes}

1 We use the term programmatics as a translation of the German term

Programmatiken. In German, the term refers to politicals statements, policies and agenda setting. A more theoretical conceptualisation of programmatic can be found in the world polity approach where it refers to social and institutionalised orders (Adlere and Weber, 2018, p. 436). In this paper, we use the term programmatics to describe the institutional orders in academic organisations, which we will analyse from a discourse perspective.

2 The term dispositive derives from the French dispositif, which is often translated as apparatus in English. As this ranslation is somewhat misleading, we follow Raffnsøe et al. $(2014$, p. 275$)$ and use the term dispositive in English.

3 The Excellence Initiative was superseded by the Excellence Strategy in 2019.

4 German Research Foundation. The DFG is a self-governing organisations proving funding for research projects and supporting early career researchers. Moreover, the DFG understands itself as, voice of science in political and social discourse" (DFG, 2019a, 2019b) and is regarded as one of the most important science policy advisors in Germany.

5 This research is a follow-up investigation of research organisations that have been part of a larger project funded by the national ministry of education and research (BMBF). This project focused on early career researchers' academic careers (Elven et al., 2018; Schwarz et al., 2018), who were interviewed in the project. To allow further analysis and triangulation of the research material, we selected these six organisations from the corpus of the 12 organisations analysed in the previous project with regard to an equal distribution of interviews with female and male early career researchers in the former project.

6 The interview was divided in four question blocks. Questions in the first block aimed at getting to know more about the institutional representatives career up to the current position and his/her experiences in the academic organisation. The second block of interview questions was addressed to the respective other institutional representative-i.e. we asked the Equal Opportunities Officer about her experiences with the topic of early-career researchers in the organisation and the workplace cooperation between the Equal Opportunities Officer and the head of the department for early-career researchers and vice versa. The third block of questions aimed at getting to know more about institutional programmatics (had they applied for the Excellence Initiative, for example). In the fourth block, the interviewees were asked to give three short statements (What would you recommend to early-career researchers? What would you say to other officials and decision-makers (which ones?) at your university/research institution? What would you like to say to the Ministry of Science?)

7 For reasons of anonymity we do not use direct quotations from the website.

8 Indeed, a performativity-oriented discourse analytical interview approach (Jergus, 2014) proofed to be very productive in that it allowed to focus on a relational constitution of meaning and of differently situated subjectivies and their discursive strategies of re-positioning themselves in the interview situation (Wieners, 2020).

9 For reasons of anonymity, the pictures of the websites cannot be disclosed here.

10 The entrepreneurial style of speaking clearly does not refer to institutional entrepreneurial strategies like academic start-up, but addresses the cultural patterns of newness and to the dispositives of creation introduced in the beginning.

\section{References}

Acosta A (2015) Buen Vivir. Vom Recht auf ein gutes Leben. Oecom Verlag

Adler A, Weber SM (2018) Programmatiken und Semantiken als Gegenstand der Organisationspädagogik. In: Göhlich M, Schröer A, Weber SM (eds) Handbuch Organisationspädagogik. Springer, Wiesbaden, pp. 433-442

Alaima S (2008) Trans-corporeal feminisms and the ethical space of nature. In: Alaimo S, Hekman S (eds) Material feminisms. Indiana University Press
Alvarez SA, Barney JB (2007) Discovery and creation: alternative theories of entrepreneurial action. Strateg Entrep J 1(1-2):11-26

Angermuller J (2010) Wissenschaft zählen. Regieren im digitalen Panopticon. Leviathan. Berliner Zeitschrift für Sozialwissenschaft. Sonderheft 25: Sichtbarkeitsregime. Überwachung, Sicherheit und Privatheit im 21, Jahrhundert, pp. 174-190

Ball SJ (2000) Performativities and fabrications in the education economy: towards the performative society. Aust Educ Res 27(2):1-23

Barnett R (2011) Being a university. Routledge, London

Beaufaÿs S (2003) Wie werden Wissenschaftler gemacht?: Beobachtungen zur wechselseitigen Konstitution von Geschlecht und Wissenschaft. Sozialtheorie. transcript, Bielefeld

Ben-David J (1968) The universities and the growth of science in Germany and the United States. Minverva 7(1 and 2):1-35

Blackmore J (2019) Feminism and neo/liberalism: contesting education's possibilities. Discourse 40(2):176-190

Bloch R (2018). Stratification without producing elites? The emergence of a new field of doctoral education in Germany. In: Bloch R, Mitterle A, Paradeise A Peter T (eds) Universities and the production of elites: discourses, policies, and strategies of excellence and stratification in higher education. Palgrave Macmillan, pp. 299-324

Braun D (2008) Evaluation und unintendierte Effekte-eine theoretische Reflexion. In: Matthies H, Simon D (eds) Wissenschaft unter Beobachtung: Effekte und Defekte von Evaluationen, vol 4. VS Verlag für Sozialwissenschaften, Wiesbaden, pp. 103-124

Bröckling U (2013) Evaluation. In: Bröckling U, Krasmann S, Lemke T (eds) Glossar der Gegenwart. Edition Suhrkamp, vol 2381. Suhrkamp, Frankfurt am Main, pp. 76-81

Bröckling U, Peter T (2017) Das Dispositiv der Exzellenz. In: Diaz-Bone R, Hartz R (eds) Dispositiv und Ökonomie: Dispositivanalytische perspektiven auf Organisationen und Märkte. VS Verlag für Sozialwissenschaften, Wiesbaden, pp. 283-303

Bührmann A (2014) Die Dispositivanalyse als Forschungsperspektive in der (kritischen) Organisationsforschung: Einige Überlegungen am Beispiel des Diversity Managements. In: Hartz R, Rätzer M (eds) Organisationsforschung nach Foucault. transcript, Bielefeld, pp. 39-60

Bührmann A, Schneider W (2016) Das Dispositiv als analytisches Konzept: Mehr als nur Praxis Überlegungen zum Verhältnis zwischen Praxis- und Dispositivforschung. $\mathrm{Z}$ Diskursforsch 1:5-28. https://doi.org/10.3262/ ZFD1601005

Burkhardt A, Harrlandt F, Schäfer J-H (2019) "Wie auf einem Basar": Berufungsverhandlungen und Gender Pay Gap bei den Leistungsbezügen an Hochschulen in Niedersachsen. Im Auftrag des Niedersächsischen Ministeriums für Wissenschaft und Kultur. HoF-Arbeitsbericht 110. Lutherstadt Wittenberg: Institut f. Hochschulforschung Wittenberg. Retrieved from https:/www.hof.uni-halle.de/web/dateien/pdf/ab110.pdf

Butler J (1996) Excitable speech: Contemporary scenes of politics. Routledge, New York

Chesbrough HW (2003) Open innovation: the new imperativ for creating and profiting from technology. Havard Business Review Press, Waterton

Clark BR (2010) The entrepreneurial university: demand and response 1. Tert Educ Manag 4(1):5-16

Destatis (2019) Professoren und Professorinnen an deutschen Hochschulen bis 2018|Statista. https:/de.statista.com/statistik/daten/studie/160365/umfrage/ professoren-und-professorinnen-an-deutschen-hochschulen/ Accessed 17 Jun 2021

Deutsche Forschungs Gemeinschaft (2019a) Excellence Initiative at a Glance: the programme by the German Federal and State Governments to promote top-level research at universities. The Second Phase 2012-2017 Graduate SchoolsClusters of Excellence-Institutional Strategies. https:/www.dfg.de/download/ pdf/dfg_im_profil/geschaeftsstelle/publikationen/exin_broschuere_en.pdf Accessed 17 Jun 2021

Deutsche Forschungs Gemeinschaft (2019b) Mission Statement. https:// www.dfg.de/en/dfg_profile/mission/index.html Accessed 10 Sept 2021

Dewey J (1929) Democracy and education: an introducation into the philosophy of education. The Macmillan Company

Dewey J (1967) A pedagogical experiment. In: Dewey J (ed) The early works of John Dewey, vol 2, 1882-1898. Southern Illinois Press, pp. 244-246

Elven J, Schwarz J, Weber S, Wieners S (2018) Organisation, Sozialisation und Passungsverhältnisse im wissenschaftlichen Feld: Potenziale qualitativer Mehrebenenanalysen für die rekonstruktive Laufbahnforschung. Z Qual Forsch 1+2:307-324

Engler S (2001) In Einsamkeit und Freiheit“?: Zur Konstruktion der wissenschaftlichen Persönlichkeit auf dem Weg zur Professur. UVK-Verlag, Konstanz

Foucault M (1971) The order of things: an archaeology of the human sciences. Pantheon Books, New York

Foucault M (1973) The archaeology of knowledge and the discourse on language. Pantheon Books, New York 
Foucault M (1977) Discpline and punishment. Pantheon Books, New York

Foucault M (1980) The confession of the flesh. In: Foucault M (ed) Power/ knowledge: selected interviews and other writings 1972-1977. Vintage Books, New York, pp. 194-228

Foucault M (1984) Of other spaces. Diacritics 16:22-27

Fraser N (2009) Feminism, capitalism, and the cunning of history. New Left Rev 56(3):97-117

Gertenbach L (2014) Die Organisation(en) der Gesellschaft-Foucault und die Gouvernmentality Studies im Feld der Organisationsforschung. In: Hartz R, Rätzer M (eds) Organisationsforschung nach Foucault. transcript, Bielefeld, pp. $151-168$

Gill R (2014) Unspeakable Inequalities: Post Feminism, Entrepreneurial Subjectivity, and the Repudiation of Sexism among Cultural Workers. Soc Politics 21(4):509-528

Goldan L (2019) Gleicher Titel, ungleiche Entlohnung. Geschlechtsbezogene Lohnunterschiede unter Promovierten in Deutschland. GENDER - Zeitschrift Für Geschlecht. Kult Ges 11(2):103-120

Hamann J (2016) "Let us salute one of our kind." How academic obituaries consecrate research biographies. Poetics 56:1-14

Hammarfelt B, de Rijcke S, Wouters P (2017) From eminent men to excellent universities: university rankings as calculative devices. Minerva 55(4):391-411

Jergus K (2014) Die Analyse diskursiver Artikulationen. Perspektiven einer poststrukturalistischen (Interview-)Forschung. In: Thompson C, Jergus K, Breidenstein G (eds) Interferenzen: Perspektiven kulturwissenschaftlicher Bildungsforschung. Velbrück, Weilersvist, pp. 51-70

Jones DR, Visser M, Stokes P et al. (2020) The Performative University: 'Targets', 'Terror' and 'Taking Back Freedom' in Academia. Manag Learn 51(4):363-377

Kahlert H (2015) Nicht als Gleiche vorgesehen. Über das "akademische Frauensterben” auf dem Weg an die Spitze der Wissenschaft. Beitr Hochschulforsch 37(3):60-78

Kamper G (2003) Kreativität und Wissenskunst: Versuch über eine Entwicklungsrichtung von Wissenschaft und deren Bedeutung für eine neue Pädagogik. Lang, Frankfurt a.M

Krais B (2000) Das soziale Feld Wissenschaft und die Geschlechterverhältnisse: Theoretische Sondierungen. In: Krais B (ed) Wissenschaftskultur und Geschlechterordnung. Über die verborgenen Mechanismen männlicher Dominanz in der akademischen Welt. Campus, Frankfurt, pp. 32-54

Kreckel R (2016) Zur Lage des wissenschaftlichen Nachwuchses an Universitäten: Deutschland im Vergleich mit Frankreich, England, den USA und Österreich. Beiträge Zur Hochschulforschung, 38(1-2): 12-40

Kühl S (2011) Organisationen: Eine sehr kurze Einführung. VS Verlag für Sozialwissenschaften, Wiesbaden

Link J (2010) Dispositiv. In: Kammler C, Parr R, Schneider UJ, Reinhardt-Becker E (eds) Foucault-Handbuch: Leben - Werk - Wirkung. Verlag J.B. Metzler, Stuttgart, Weimar, pp. 237-242

Maasen S, Weingart P (2008) Unternehmerische Universität und neue Wissenschaftskultur. In: Matthies H, Simon D (eds) Wissenschaft unter Beobachtung: Effekte und Defekte von Evaluationen, vol 24. VS Verlag für Sozialwissenschaften, Wiesbaden, pp. 141-160

Maasen S (2010) Neurogouvernementality ahead? Diskursanalytische Untersuchungen am Beispiel des Experimentalsystem Neuropädagogik. In: Angermüller J, van Dyk S (eds) Diskursanalyse meets Gouvernementalitätsforschung: Perspektiven auf das Verhältnis von Subjekt, Sprache, Macht und Wissen. Sozialwissenschaften. Campus-Verlag, Frankfurt a.M., pp. 183-206

Mareis C (2011) Design als Wissenskultur. Interferenzen zwischen Design- und Wissensdiskursen. transcipt, Bielefeld

Marginson S, Considine M (2000) The enterprise university: power, governance and reinvention in Australia. Cambridge University Press, Cambridge

Marx-Ferree M, Zippel K (2015) Gender equality in the age of academic capitalism: gender equality in the age of academic capitalism: discursive intersections and university restructuring. Soc Politics 22(4):561-584

Masschelein J, Simons M (2012) Globale Immunität oder: Eine kleine Kartographie des europäischen Bildungsraums. Diaphanes, Zürich

McRobbie A (2004) Post-feminism and popular culture. Fem Media Stud $4(3): 255-264$

McRobbie A (2010) Top girls: Feminismus und der Aufstieg des neoliberalen Geschlechterregimes. VS Verlag für Sozialwissenschaften, Wiesbaden

Miller P, Rose NS (2008) Governing the present: administering economic, social and personal life. Polity Press, Cambridge

Münch R (2014) Academic capitalism: universities in the global struggle for excellence. Routledge, New York

Narr W-D (2011) Wider die öffentlich und privat verordnete Verdummung im Zeichen von »Exzellenz« Für Lernprozesse mit Menschen dienlichem Anfang und Ende. In: Lohmann I, et al., (eds) Schöne neue Bildung? De Gruyter, Berlin, pp. 209-223

Parr R (2010) Diskurs. In: Kammler C, Parr R, Schneider UJ, Reinhardt-Becker E (eds) Foucault-Handbuch: Leben - Werk - Wirkung. Verlag J.B. Metzler, Stuttgart, Weimar, pp. 233-237
Peters MA (2001) Education, enterprise culture and the entrepreneurial self. J Educ Enq 2(2):58-71

Peters MA (2002) The university in the knowledge economy. In: Cooper S, Hinkson J, Sharp G (eds) Scholars and entrepreneurs: the universities in crisis. Arena Publications, Melbourne, pp. 137-152

Peters MA (2019) Managerialism and the Neoliberal University: prospects for new forms of 'open management' in higher education. In: Peters MA, Weber SM (eds) Organization and newness. Brill Sense, Leiden, pp. 135-148

Raffnsøe S, Gudmand-Høyer M, Thaning MS (2014) Foucault's dispositive: The perspicacity of dispositive analytics in organizational research. Organization 23(2):272-298

Riegraf B, Weber L (2017) Excellence and gender equality policies in neoliberal universities. Gend Výzkum/Gend Res 18(1):92-112

Rottenberg C (2014) The rise of neoliberal feminism. Cult Stud 28(3):418-437

Schmeiser M (1994) Akademischer Hasard: Das Berufsschicksal des Professors und das Schicksal der deutschen Universität 1870-1920; eine verstehend soziologische Untersuchung. Klett-Cotta, Stuttgart

Schwarz J, Weber SM, Wieners S (2018) Spacing career paths: institutionalized positioning practices within the academic field. In: Glaser E, Koller H-C, Thole W, Krumme S (eds) Räume für Bildung. Räume der Bildung. Beiträge zum 25. Kongress der Deutschen Gesellschaft für Erziehungswissenschaft. Barbara Budrich Publishers, Opladen, pp. 88-98

van Leeuwen T (2011) Multimodality and Multimodal Research. In: Margolis E, Pauwels L (eds), The SAGE handbook of visual research methods. Sage Publications Ltd, pp. 549-569

Weber L (2017) Die unternehmerische Universität: Chancen und Risiken für Gleichstellungspolitiken in Deutschland, Großbritannien und Schweden. Arbeitsgesellschaft im Wandel. Beltz Juventa, Weinheim

Weber M (1921) Wissenschaft als Beruf. Duncker \& Humblot, München

Weber SM (2006) Der ,Intrapreneur' und die ,Mutter'. Pädagogische Gouvernementalität am Kreuzungspunkt von Ökonomie und Bevölkerung. In: Weber SM, Maurer S (eds) Gouvernementalität und Erziehungswissenschaft: Wissen, Macht, Transformation. VS Verlag für Sozialwissenschaften, Wiesbaden, pp. 139-162

Weber SM (2013b) Dispositive des Schöpferischen: Genealogie und Analyse gesellschaftlicher Innovationsdiskurse und institutioneller Strategien der Genese des Neuen. In: Rürup M, Bormann I (eds) Innovationen im Bildungswesen. Springer Fachmedien, Wiesbaden, pp. 191-221

Weber SM, Heildemann M-A (2019) Mindfulness in sustainability. creating capacity for social renewal from within. In: Filho LW (ed.) Encyclopedia of sustainability in higher education. Springer, Cham

Weber SM, Tascón MA (2020) Pachamama - La Universidad del "Buen Vivir": a first nations sustainability University in Latin America. In: Walter L (ed) Universities as living labs for sustainable development. Springer, Cham, pp. 849-862

Weber SM, Wieners S, Grosse L (2018) Das Netz der Organisation und seine Oberflächen. In: Weber SM, Truschkat I, Schröder C, Peters L, Herz A (eds.) Organisation und Netzwerke. VS Verlag für Sozialwissenschaften, Wiesbaden, pp. 83-91

Weber SM (2013a) Imagining the creative university. dispositives of creation, strategies of innovation, politics of reality. In: Peters MA, Besley T (eds) The Creative University. Sense Publishers, pp. 161-192

Weber SM (2018) Strategieentwicklung als Gegenstand der Organisationspädagogik. In Göhlich M, Schröer A, Weber SM (eds) Handbuch Organisationspädagogik. Springer, Wiesbaden, pp. 595-606

Weber SM (2020) MOOCs, CAPs, U.Labs \& CO: translational settings and translational strategies in global digital temporary organizations. In: Trans/ Wissen (eds) Transnationalisation and knowledge - the ubiquity of translation and the crisis it faces. transcript, Bielefeld, pp. 369-391

Wieners S (2020) Exzellenz und Geschlecht: Die Organisation der Verantwortung für den ,wissenschaftlichen Nachwuchs'. In: Fahrenwald C, Engel N, Schröer A (eds) Organisation und Pädagogik. Organisation und Verantwortung: Jahrbuch der Sektion Organisationspädagogik. SpringerVS, Wiesbaden, pp. 183-196

Wieners S, Weber SM (2019) Das Dispositiv als Methodologie in der Geschlechterforschung. In: Kubandt M, Schütz J (eds) „Gerne Geschlecht?!“Methoden und Methodologien in der erziehungswissenschaftlichen Geschlechterforschung. Budrich, Opladen, pp. 180-196

Zorn C (2008) Kreativität und Veränderung. Von der neusten Prüfung für die Legitimität der Neuzeit. Z Kulturwissensch: Kreativität Eine Rückholaktion $1: 69-85$

\section{Acknowledgements}

This research was funded by the Hessian Ministry of Science and Arts from 12/2017 to 08/2019 in the funding scheme "Dimensionen der Kategorie Geschlecht-Frauen und Geschlechterforschung in Hessen. 


\section{Funding}

Open Access funding enabled and organized by Projekt DEAL.

\section{Competing interests}

The authors declare no competing interests.

\section{Additional information}

Correspondence and requests for materials should be addressed to Sarah Wieners.

Reprints and permission information is available at http://www.nature.com/reprints

Publisher's note Springer Nature remains neutral with regard to jurisdictional claims in published maps and institutional affiliations. (c) (i) Open Access This article is licensed under a Creative Commons Attribution 4.0 International License, which permits use, sharing, adaptation, distribution and reproduction in any medium or format, as long as you give appropriate credit to the original author(s) and the source, provide a link to the Creative Commons license, and indicate if changes were made. The images or other third party material in this article are included in the article's Creative Commons license, unless indicated otherwise in a credit line to the material. If material is not included in the article's Creative Commons license and your intended use is not permitted by statutory regulation or exceeds the permitted use, you will need to obtain permission directly from the copyright holder. To view a copy of this license, visit http://creativecommons.org/ licenses/by/4.0/.

(C) The Author(s) 2021 